\title{
持続可能な発展の目標からみた 総合計画の評価の試み
}

\author{
松橋 啓介 1 ・永野 亜紀 2 \\ 1正会員 国立環境研究所 社会環境システム研究センター（テ305-8506 茨城県つくば市小野川16-2） \\ E-mail:matuhasi@nies.go.jp \\ 2非会員 国立環境研究所社会環境システム研究センター（テ305-8506 茨城県つくば市小野川16-2）
}

\begin{abstract}
国連を中心に持続可能な発展目標が議論されている. 持続可能な発展を実現するためには, その目標を 総合計画に位置付け, 戦略的に取り組むことが効果的である. 本研究は, 環境面で先進的な23の環境モデ ル都市を例に, 総合計画の基本目標を分解し, 別に設定した包括的な目標の項目と対応付け, 持続可能な 発展に関する目標の4分野が各々占める割合を評価した。その結果，環境面の項目の割合が少ないこと， 見出し語を分析対象とした場合に特に少ないことが分かった。 今後, 地域の上位ビジョンに持続可能な発 展の目標をバランスよく示すことが望ましい.
\end{abstract}

Key Words : Sustainable Development Goals, Eco Model City, comprehensive plan, policy evaluation

\section{1. はじめに}

2015年以降の国際開発目標として，「持続可能な開発 目標（SDGs, Sustainable Development Goals）」が国連を中 心に検討されている. ミレニアム開発目標（MDGs）を 踏まえて，新たに先進国を対象に加えた統合的な目標で ある.わが国においても，持続可能な開発および発展に 関する目標の設定とその達成に向けた議論が活発になる ことが予想される.

第四次環境基本計画では，目指すべき持続可能な社会 について，安全が確保されることを前提として，低炭 素・循環・自然共生の各分野が統合的に達成され，健全 で恵み豊かな環境が地球規模から身近な地域にわたって 保全される社会としている，他方で，資本主義や経済成 長の行き過ぎへの反省から，幸福度指標が注目され，経 済社会状況や健康, 関係性の改善による幸福感の向上が 公共政策の重要な目標の一つとなりつつある1). これら を踏まえると，持続可能な社会の実現に実効性を持たせ るためには，現世代の幸福感と将来世代の幸福感の両立 を目指して，生活の質等と持続可能性を同時に向上させ ることが鍵となる.こうした観点から持続可能な発展の 目標を定めて，その達成を目指すことが，改めて重要な 課題になると考えられる.

持続可能な発展を実現するためには，'Think Globally, Act Locally”の言葉に代表されるように，地域における取
り組みが重要である。また，先進地域においてモデル的 な取り組みを行い，後に全国へ普及させる環境モデル都 市や環境末来都市のようなアプローチも有効であろう. 特に，環境面の目標を環境基本計画や環境モデル都市提 案に位置付けるだけでなく, 中長期的な持続可能な発展 の目標を地方自治体の総合計画に位置付ける 2 とともに， その実現に向けた施策の効果を把握しながら体系的かつ 戦略的に取り組むことが効果的と考えられる.

そこで本研究では，環境面において先進的と考えられ る環境モデル都市を例にとり，総合計画における基本目 標や都市像の文言を分析し，持続可能な発展の目標に相 当する内容が含まれる割合を試行的に評価することで, その特徴を把握するとともに，分析・評価方法の課題と， 持続可能な発展の目標を総合計画に位置付ける際の課題 を明らかにすることを目的とする。これらの知見により， 持続可能な発展戦略の立案や普及に役立てることを目標 とする.

\section{2. 分析・評価の枠組みと方法}

\section{(1) 既往研究とそれを踏まえた分析の枠組み}

持続可能な発展の観点から総合計画を分析した研究と しては，都道府県・政令指定都市の総合計画を対象に 「持続可能」や「持続的発展」といった用語の使用状況 
を調査したもの3)と，これを踏まえ，持続可能な都市づ くりに向けて，制度や人工資本，人的資本，知識，自然 資本からなる生産的基盤を維持・向上させる必要がある と指摘したもの出が挙げられる。しかし，生活の質等を 構成する要素については，そもそも決めることが難しい 上に，計測や政策的なコントロールが極めて困難である として, 持続可能な発展の目標に関する具体的な内容を 踏まえた分析は行っていない.

一方，欧州24力国の持続可能発展戦略を分析し，EU 持続可能発展戦略の目標や指標との適合度を評価した研 究5がある. 目標に関してはYes／Noで，7つの主要チヤ レンジと4つの横断的政策の各々について, 各国とEUと の目標の類似性を判別している．指標に関しては4段階 で，EUの10のヘッドラインとの類似性を定量化してい る. 前者と類似のアプローチを用いて日本の自治体にお ける総合計画の基本目標等の比較評価を試みた ${ }^{6)}$ が，総 合計画の構成や形式のばらつきが結果に大きく影響する ため, 比較可能な定量化を行うためにはさらなる工夫が 必要と考えられた.

また，SDGののレポートでは，16のゴールを対象とし て，各々に含まれるターゲットごとに対応するゴールお よびターゲットの数を種類ごとに集計することで, 環境, 経済, 社会の要素が各ゴールに占める割合を定量化して いる7. しかし，その手続きやゴールおよびターゲット と要素との関連性が明示されておらず, 再現性が十分に 担保されていない. 再現性の確保の点では, 都市計画マ スタープランを対象にコンパクトシティ政策抽出マニュ アルを作成し, キーワード抽出に加えて, 捉え方, 実現 策, 相反する記述といった文脈にも目を向け，客観的に 分析した研究8)のアプローチも参考になる.

これらを踏まえて, 本研究では, 総合計画の基本目標 や都市像を対象に持続可能な発展の目標が占める割合を 分析する方法を検討した．まず，日本の地方自治体にお ける持続可能な発展の目標を評価する際の標準となりう る枠組みを得るべく, 持続可能な発展を支えるトリプル ボトムラインである環境, 経済, 社会に, 個人の生活の 質を加えた4分野に着目して，その具体的な内容を検討 した上で，包括的な目標の項目を定める. 次に，対象計 画に含まれる基本目標等とその説明文に着目して，それ らの文言を一定の手順に沿って分析することで，目標全 体に占める環境，経済，社会，個人の各目標の割合を定 量化する.

\section{（2）包括的な目標の項目の設定}

\section{a) 学問分野によるアプローチの違い}

持続可能な発展の目標は，地域社会によって異なって おり，共通的な内容を定めることは容易ではない，たと えば，経済学的アプローチでは，構成要素を測ることは
できないため, 決定要因を計測する苞としつつ，その幸 福度への貢献度を直接測る試みが行われつつある. 一方, 社会学的アプローチでは, 達成目標は多種多様として, その多様さに着目した現況の把握と分類を得意とする.

ここでは，工学的アプローチを採用し，目標をできる だけ漏れなく重なりなく包括する項目を定めることを試 みる. これにより, 持続可能な発展の目標の全体像を分 かりやすくし，分析・評価に取り組むことを可能とする. b) 4分野と4資本

持続可能な発展の目標における4分野の内容は，叙述 シナリオ構築のために行った4分野12項目の整理)を踏ま えて，具体的な検討をさらに重礼て定めた。 なお，4分 野は, 持続可能性指標の一例であり, 日本一の適用事例 10)もあるコンパスに基づいている。環境(Nature), 経済

(Economy), 社会(Society), 個人(human Welfare)の頭文字を, 4つの方位North, East, South, Westの頭文字に対応させたも の11)である.

経済, 社会, 生活の質等からなる幸福度と, 経済, 社会, 環境等からなる持続可能性とを兼ね合わせ，社会の持続 可能な発展の方向性を表しているともいえる. また, 包 括的な富の基盤として，自然資本，人工資本，人的資本 に知識を加えたアプローチ12)や，知識の代わりに社会関

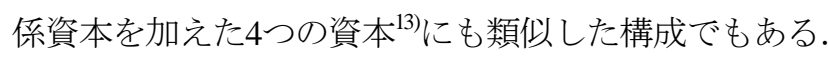

\section{c) ワークショップ形式の検討}

地域SDI（持続可能性指標）研究プロジェクト関係者7 名が参加し，地域における持続可能性評価に適した分野 と項目を選定するワークショップ形式の作業を2012年12 月に行った.

上述のコンパスを適用した日本の持続可能性指標やド イツのノルトラインウェストファーレン州の持続可能性 指標で用いられた項目を分類作業の材料とした. なお, 環境, 経済, 社会, 個人のレベルを分野と呼び, 分野と 指標の間のレベルで，分野の具体的な範囲と内容を3〜5 つ程度で示寸ものを項目と呼ぶ.

項目を4分野に分類し，他の指標等で用いられる項目 を追加し，類似の項目同士を近くに並び替え，ひもを用 いてグルーピングを自在に変更しながら，境界線にまた がる項目各々の特質について議論を重ね, 分野を構成す る項目を明らかにする作業をおよそ2時間で行った.

同様に，持続可能社会転換方策研究プロジェクト関係 者16名が参加し, 地域における持続可能な発展の目標に 関する分野と項目を選定し，現況評価や重み付けを試み るワークショップ形式の作業を2013年10月に行った.

4分野の目標それぞれについて，内容を表寸項目を3つ 挙げ，また，その項目を代表する指標を定量・定性関わ りなく考える事前作業を各自が行い, 当日の分類作業の 材料とした.

項目を4分野に分類し，項目の追加，並べ替え，グル 
ーピングを行った.これに加えて, 指標の選定, 現況值 の評価，項目間および分野間の重み付けをあわせておよ そ6時間の作業を行った。

その後さらに，地域SDI研究における4資本のストック 指標と4分野の達成目標指標の検討作業や，NPO法人

「環境自治体会議」加盟7自治体が参加する研究会合に おける議論と見直しを重ねて，分析に用いる包括的な目 標の12項目を表-1の通り設定した.

\section{d) 議論の分かれる点}

その際に, 以下の点が議論となった. 今後も引き続き 検討すべき余地がある点として挙げておく.

4資本アプローチでは，インフラ（社会基盤施設）が 注目されや寸い，しかし，人口減少社会では，空き家や 施設の適正配置，そのための財政支出が主要な課題とな っており，価值のある資本と一概にみな寸ことには疑問 がある. そのため, 経済の均衡に関する項目に含めた.

雇用は，日常生活を支える収入を生み出し，生きがい につながる仕事を提供し，社会参加の場でもある等，多 くの項目に関わりうる，その中で，特に，経済分野にお ける格差や貧困の問題の重要性に注目して, 適正な雇用 を分配の項目に含めた.

基本的人権は, 個人の選択機会や能力開発にも関連寸 る.ここでは，社会を構成するための重要な社会的規範 としての性質に注目した. 社会の分野は, 定量化も項目 の設定ももっとも難航した．多様な切り口がありうるが, 近代的でグローバルな社会的規範と, 伝統的でローカル なコミュニティを対置させ，その仲立ちとして，統治に 関連する対応力を項目として設定する整理とした.

環境は, 資源, エネルギー, 生態系とした. 循環型, 低炭素, 自然共生に対応寸る. 安心は個人の生活の質, 安全は社会の対応力, 公害等の環境質に関する問題は個 人の身体的健康で扱うこととした。

また，近年の幸福度あるいは持続可能性に関する検討 結果と比較しておく，OECDのBetter Life Index ${ }^{149} の 11$ 項目 と比較すると，全体的に類似しており，主観的な生活満 足度を含まず，大気污染や水質保全を指寸環境を3項目 へと強化している点が特徵である. UNEP/UNU-IHDPの Inclusive Wealth Index ${ }^{15)}$ の18項目と比較すると, 個人面之 社会面が充実している点が異なる. 全般的に，包括的な 項目を選定することができたと考えられる.

\section{（3）総合計画における基本目標の分析の方法 a) 対象とする総合計画の選択}

環境モデル都市23都市の総合計画を分析対象として選 択し，その基本構想を収集した．環境モデル都市は，温 室効果ガスの大幅な削減など高い目標を掲げ，低炭素社 会の実現に向けて先駆的な取り組みにチャレンジする都 市である. 表-2に示寸通り，2008年度13都市，2012年度
表-1 地域における持続可能な発展の目標を包括する4分野12 項目として設定した内容

\begin{tabular}{|c|c|c|}
\hline 分野 & 項目 & キーワード \\
\hline \multirow{3}{*}{ 個人 } & 人生の質 & 選択機会、能力開発、期待、記憶 \\
\hline & 生活の質 & 元気、安心、精神的健康 \\
\hline & 身体的健康 & 平均余命、環境質 \\
\hline \multirow{3}{*}{ 社会 } & 社会的規範 & 人権、公正、国際協力 \\
\hline & 対応力 & 統治、安全、参加、信頼、協働 \\
\hline & コミュニティ & 互助、地元愛、歴史·文化 \\
\hline \multirow{3}{*}{ 経済 } & 分配 & 貧困、適正な雇用 \\
\hline & 均衡 & 財政、金融、インフラ \\
\hline & GDP & 生産性、購買力 \\
\hline \multirow{3}{*}{ 環境 } & 資源 & 鉱物、材料、循環 \\
\hline & エネルギー & 気候 \\
\hline & 生態系 & 水、土地、窒素、生物、遺伝子 \\
\hline
\end{tabular}

表-2 分析対象とする自治体と基本目標等の名称

\begin{tabular}{|c|c|c|c|c|c|}
\hline No. & 策定年 & 目標年 & 自治体名 & 名称 & 見出し数 \\
\hline \multicolumn{6}{|c|}{ 2008年度選定都市 } \\
\hline (1) & 2011 & 2018 & 下川町 & 基本目標 & 6 \\
\hline (2) & 2010 & 2019 & 帯広市 & まちづくりの目標 & 8 \\
\hline (3) & 2001 & 2018 & 千代田区 & 施策のみちすじ & 4 \\
\hline (4) & 2006 & 2025 & 横浜市 & 都市像を支える5つの柱 & 5 \\
\hline (5) & 2007 & 2016 & 飯田市 & 基本目標 & 5 \\
\hline (6) & 2007 & 2016 & 富山市 & まちづくりの目標達成のための施策 & 4 \\
\hline (7) & 2008 & 2017 & 豊田市 & めざすべき姿 & 3 \\
\hline (8) & 1999 & 2025 & 京都市 & 市民のくらしとまちづくり & 3 \\
\hline (9) & 2001 & 2020 & 堺市 & まちづくりの目標と基本方向 & 4 \\
\hline (10) & 2010 & 2020 & 梼原町 & 施策体系 & 6 \\
\hline (11) & 2008 & 2018 & 北九州市 & 基本方針 & 4 \\
\hline (12) & 2010 & 2017 & 水俣市 & 施策の大綱 & 5 \\
\hline (13) & 2007 & 2016 & 宮古島市 & 施策の大綱 & 6 \\
\hline \multicolumn{6}{|c|}{ 2012年度選定都市 } \\
\hline (14) & 2007 & 2014 & 新潟市 & 都市像 & 5 \\
\hline (15) & 2005 & 2014 & つくば市 & 施策の大綱 & 8 \\
\hline (16) & 2006 & 2015 & 御嵩町 & 施策の体系 & 6 \\
\hline (17) & 2013 & 2022 & 尼崎市 & ありたいまち & 4 \\
\hline (18) & 1993 & 2025 & 神戸市 & 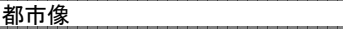 & 5 \\
\hline (19) & 2012 & 2021 & 西粟倉村 & それぞれの分野が目指す姿 & 5 \\
\hline (20) & 2013 & 2022 & 松山市 & まちづくりの基本目標 & 6 \\
\hline \multicolumn{6}{|c|}{ 2013年度選定都市 } \\
\hline (21) & 2012 & 2023 & 二セコ町 & 基本理念を支える5つの将来像 & 5 \\
\hline (22) & 2009 & 2018 & 生駒市 & まちづくりの目標 & 5 \\
\hline (23) & 2009 & 2018 & 小国町 & まちづくりの基本目標·施策の大綱 & 4 \\
\hline
\end{tabular}

7都市，2013年度3都市が選定されている．

これらの都市は, 従来から環境配慮型の自治体として も知られているものが多く, 他の都市に比較して, 環境 面の目標を総合計画に反映させている可能性が高いと考 えられる.また，多様な都市規模の中から選定されてい る点も特徵であり, 分析作業量も考慮して, 試行のサン プルとして適していると判断した．なお，2011年度には 環境未来都市11都市が選定されたが，うち被災地域が6 件であり，被災地域以外では，下川町，柏市他，横浜市， 富山市，北九州市の5件である. 後者のうち柏市を除く 4 都市は環境モデル都市でもあることから，環境未来都市 は分析対象には含めないこととした。

\section{b) 基本目標等に相当する見出し語の選択}

次に，総合計画の基本構想の中から，基本目標等に相 当する見出し語を分析対象として選択した. 自治体のビ ジョンや目標や方針は，基本構想の中で何段階かの構成 に分けて記述されている. その各段階の名称や含まれる 内容および見出し語の数の観点から, 表-2に示寸段階の 基本目標等を分析対象に選定した. 名称と内容が必ずし 
も対応していない場合には，内容において基本目標や都 市像等を具体的に述べていることを重視した．見出し語 の数については，見出し語を分解した上で，4分野12項 目との対応付けを行うことから，4６個程度を標準と考 えた. 計画策定時に度重なる検討を経て限られた数に絞 り込まれた基本目標等の文言には，その自治体が重視す る目標のバランスが反映されているものと想定して見出 し語に着目した.

なお，見出しの下の詳細な解説には，見出しに反映さ れないより幅広い内容が記入されている場合があったた め, 詳細文を含めた分析も別途行った. 一方，一つの文 章で表現された将来像を分析するアプローチも試みたが, 抽象的な表現が多く, 文脈を把握することが困難であっ た. また，基本構想全体のテキストマイニングを行う方 法も試みたが，用語の一般的な意味での使用や繰り返し 等が多く，重要度を分析することは困難であった.

\section{c) 見出し語の分解と分類}

まず, 表-3に示すように一つの見出し語に含まれる要 素を必要に応じて2〜3個に分解し, 表-1に設定した項目 やキーワードとのあてはまりの観点から，項目との対応 付けを行った. なお，一部の表現が抽象的な場合には， 詳細説明を手掛かりに主旨を解読した上で，対応付けを 行った。 たとえば，表-3の環境行動都市については， 地球環境問題への取り組みを指寸ものとして分析した.

次に，基本目標等を構成する複数の見出し語の各々は， 相互に等しい重みを持つと考えた。すなおち，ある自治 体が将来達成したい目標全体に対して各見出し語が均等 の割合を占めることとする．さうに，各々の見出し語を 分解した数に応じて, 対応付けを行った各項目が重みを 有すると考えた. 最後に，全体に対する割合を求め，集 計した.

たとえば，基本目標を構成する5つの見出し語のうち の1つに着目し，2つに分解したうちの1つが経済のGDP に関する目標である場合，5分の1に2分の1を乗じた10分 の1が，目標全体に経済のGDPが占める割合となる。こ れらの割合を積算することで，目標全体に占める各項目

表-3 見出し語の分解と対応付けの例（横浜市）

\begin{tabular}{|l|l|l|l|l|}
\hline \multicolumn{1}{|c|}{ 見出し語 } & \multicolumn{2}{|c|}{ 分解したキ一ワード } & \multicolumn{2}{|c|}{ 対応する項目 } \\
\hline $\begin{array}{l}\text { 世界の知が集まる } \\
\text { 交流拠点都市 }\end{array}$ & $\begin{array}{l}\text { 交流拠 } \\
\text { 点都市 }\end{array}$ & & $\begin{array}{l}\text { 社会的 } \\
\text { 規範 }\end{array}$ & \\
\hline $\begin{array}{l}\text { 新たな活躍の場を } \\
\text { 開拓する活力創造都市 }\end{array}$ & $\begin{array}{l}\text { 活カの } \\
\text { 創造 }\end{array}$ & $\begin{array}{l}\text { 活躍の場 } \\
\text { の開拓 }\end{array}$ & GDP & $\begin{array}{l}\text { 適 正な } \\
\text { 雇用 }\end{array}$ \\
\hline $\begin{array}{l}\text { 多様な働き方や暮らしが } \\
\text { できる生活快適都市 }\end{array}$ & $\begin{array}{l}\text { 多様な } \\
\text { 働き方 }\end{array}$ & 生活快適 & $\begin{array}{l}\text { 適 正な } \\
\text { 雇用 }\end{array}$ & $\begin{array}{l}\text { 生 活の } \\
\text { 質 }\end{array}$ \\
\hline $\begin{array}{l}\text { 市民の知恵がつくる } \\
\text { 環境行動都市 }\end{array}$ & $\begin{array}{l}\text { 地球環 } \\
\text { 境問題 }\end{array}$ & & 気候 & \\
\hline $\begin{array}{l}\text { いつまでも安心して } \\
\text { 暮らせる安全安心都市 }\end{array}$ & 安心 & 安全 & 生活の & 対応力 \\
\hline
\end{tabular}

の割合を求めることができる.

なお，詳細説明の文を含めた分析を別途行った．見出 し語の下位の段落や，後に続く章等に，もう一段詳しい 解説があり，見出し語に反映されないより幅広い内容が 記入されている構成がみられるためである。この場合に は，文章の単位で主旨を読み取り，項目に該当する部分 を抽出した上で，見出し語の場合と同様に分類と集計を 行った。詳細説明の分析からは，各々の説明におおむね 2〜5個程度，最大で8個の項目が抽出された.

\section{3. 持続可能な発展からみた総合計画の評価}

包括的な目標の項目の設定を踏まえて，基本目標等の 見出し語を分析した結果を図-1に，その詳細説明を分析 した結果を図一に示す.

\section{(1) 見出し語での分析}

持続可能な発展の実現可能性を上げるためには，環境， 経済，社会の統合的な向上 ${ }^{16}$ が目標に含まれるとともに， 持続可能性のみならず個人の生活の質の向上も目標にバ ランス良く含まれることが重要である. 図-1に示寸通り， 個人に関する項目はすべての都市の基本目標等に含まれ ている．社会に関する項目は北九州市を除いて含まれて おり，経済に関する項目も新潟市を除いて含まれている。 その一方，環境に関寸る項目は，まったく含まない都市 が9都市ある．また，環境に関する項目を含む都市であ っても，自然環境一般や生態系を目標とする場合が多く， ニセコ町を除いては目標全体に占める割合が20\%以下と 比較的小さい結果となった.

全体的にみても, 個人や社会, 経済に関する項目が占 める割合が比較的高い傾向にある．また，環境モデル都 市であっても, 総合計画の基本目標等の見出し語におい ては，環境や低炭素・省エネルギーに関する項目が反映 されず，バランスの良い持続可能な発展の目標を持って いない都市が多くみられることが分かった，なお，見出 し語の数や分解の個数が限られているため, 包括的な目 標の項目に十分に対応する結果はそもそも得られにくい ことに留意する必要がある.

なお，表-2とあわせて考察すると，環境に関する項目 を含まない9都市のうち，総合計画策定年が環境モデル 都市選定年より前の都市は，千代田区，京都市，堺市， 神戸市，小国町である. 同年の都市は北九州市. 環境モ デル都市選定後に総合計画を策定した都市は下川町, 梼 原町，尼崎市である．環境に関する項目を含む都市では， 選定前の策定は9都市，選定後の策定が3都市，同年が2 都市であり，環境モデル都市選定後に総合計画を策定し た場合ほど環境に関する項目が多いという傾向はみられ 
$\begin{array}{llllll}0 & 20 \% & 40 \% & 60 \% & 80 \% & 100 \%\end{array}$

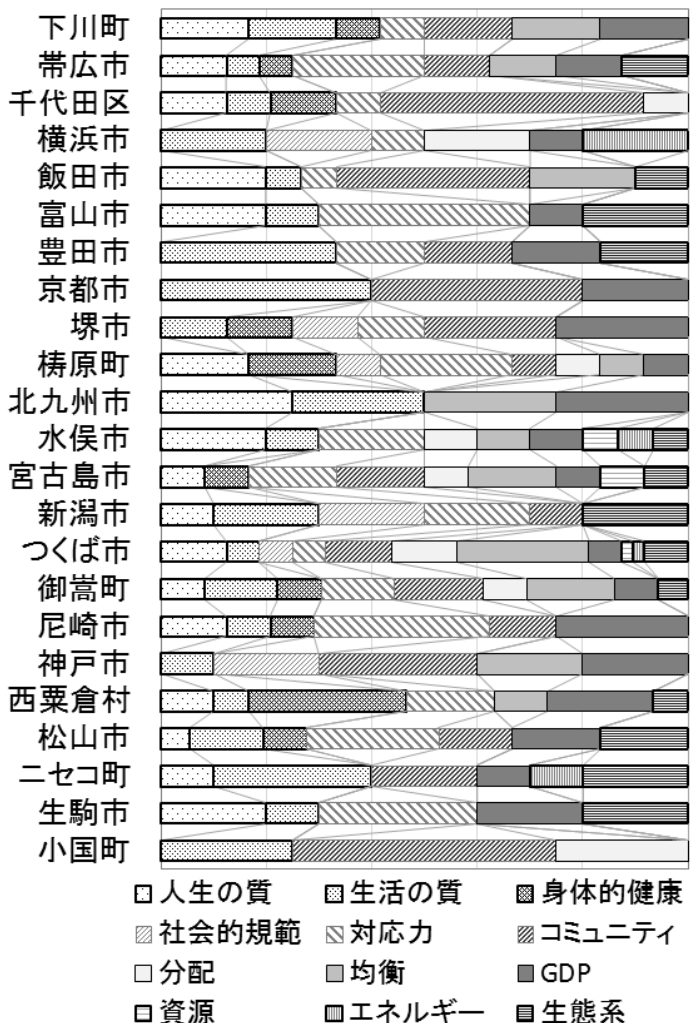

図-1 総合計画の目標に持続可能な発展の項目が占める割合 （見出し語の分析）

ない．また，自治体の人口規模や見出しの数の違いによ る差異も特に観察されない.

\section{(2) 詳細説明での分析}

図-2に示寸通り，詳細説明を分析対象とすることによ って，持続可能な発展の目標として望ましい比較的バラ ンスの取れた都市が多く見られる結果となった。環境に 関する項目が表れる都市が見られ，全体的にみても占め る割合が3ポイント増加した。環境に関する項目を含ま ない2都市のうち, 梼原町は, 基本構想が地域ビジョン のイメージ図と6つの施策の体系で構成されており，分 析対象として適切な基本目標を抽出できていない可能性 がある。

\section{（3）基本目標における持続可能な発展の目標の特徵と 位置付ける際の課題}

詳細説明まで夕ていくと環境の項目が含まれる傾向に ある. しかし，その場合でも，個人 : 社会 : 経済 : 環境 の項目の割合は, $20: 40: 27: 13$ と, 社会, 経済, 個人 の順に高く，環境の割合は高くない，これは，都市にお いて，環境をまもること自体は目標ではないが，社会や 経済の目標を達成するために，環境の項目も重要になる とする考え方が採用されているためと推測される。これ までの考え方に立つのであれば，こうした整理が選択さ $\begin{array}{llllll}0 & 20 \% & 40 \% & 60 \% & 80 \% & 100 \%\end{array}$

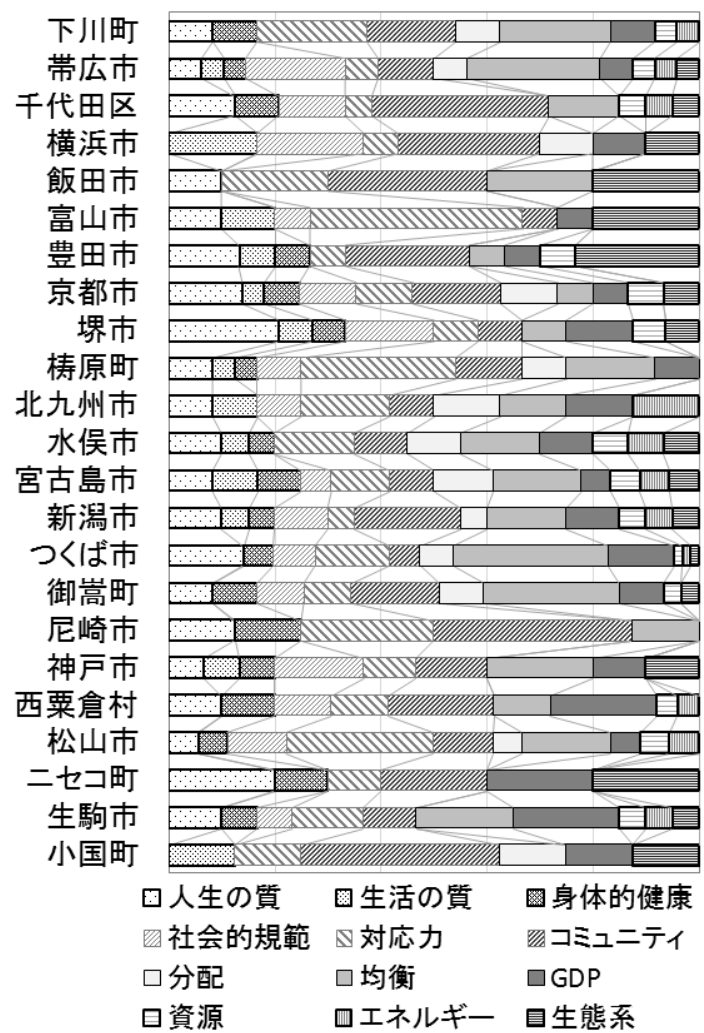

図-2 総合計画の目標に持続可能な発展の項目が占める割合 (詳細説明の分析)

れ続けることは妥当といえる.

しかし，幸福度への短期的，直接的な貢献をもたらす 環境の側面に絞って保全するのではなく，中長期的に持 続可能な都市・地域の実現をより確実に目指すというこ とであれば，上位の見出し語に環境の項目を位置づける こと, 詳細説明を含めてその割合を増やすことが重要に なる．たとえば，環境面での先進性を打ち出す自治体で あれば，目標全体に環境の項目が占める割合が20\%を超 えることを目指したい，その際には，あらゆる側面を記 述して総花的にすべきということではなく，都市・地域 の特性に応じて，まもるべきもの，変えるべきもの双方 の側面から重点的な項目を明らかにした上で，基本目標 等に位置付けることが重要である.

\section{(4) 分析 · 評価手法の課題}

見出し語の分析の方が詳細説明の分析よりもやや強調 された結果が示されるものの，大まかな傾向は変わらな いことが確認された.この分析・評価手法を用いること で，基本目標等に持続可能な発展の具体的な目標を明示 した計画については，優れたバランスを高く評価するこ とができる．都市・地域の特性に応じた目標を明記した 構成を持つ将来ビジョンの策定を支援することに役立て たい.

なお，地域における包括的な目標の項目を独自に設定 
し，分析に用いた．分析結果を比較可能とするためには, 日本の自治体に適した標準や共通的なリストを設定する ことが重要である.しかし，今回設定した項目について は，2.(2)d)の通り議論の分かれる点があるため，引き続 き検討を重ねて改良を行うことが必要である.

また，総合計画の基本構想の構成が異なるため，基本 目標等の段階を絞り込むことには若干の困難を伴う。さ らに，総合計画の策定が自由化されたため，構成や形式 のばらつきが増える可能性がある。しかし，一方，都 市・地域の将来ビジョンを定めることの重要性は増して いる. そのため, ここでは複数人での判断の比較を行っ たが，今後は，分析例の追加，分析・評価手法の改良お よびマニュアル化を行って適用可能性を高めることが課 題となる.

\section{4. おわりに}

環境モデル都市の総合計画における基本目標等の文言 を分析し，具体的に定めた持続可能な発展の目標の項目 と対応付けて, 各項目の割合を評価することで, 環境面 の反映が少ないことを指摘した. 包括的な目標の項目や 分析・評価の方法を改良することは今後も引き続き課題 である，今後，将来ビジョンを作成する際には，重要な 基本目標等を明記する構成とし，その中に持続可能な発 展の目標を具体的に挙げることが望ましい.

謝辞 : 本研究には，国立環境研究所先導プログラム「持 続可能社会転換方策研究プログラム」(FY2011-2015)およ び環境経済の政策研究「地域内外の影響を考慮した環 境・経済・社会の評価指標と測定手法の開発」(FY20122014), JST/RISTEX「多世代参加型ストックマネジメン 卜手法の普及を通じた地方自治体での持続可能性の確 保」(FY2014-2017)の成果を含む. また，初期の分析に貢 献した村山麻衣氏，林和眞氏，項目の検討に貢献した木 下裕介氏，栗島英明氏，田崎智宏氏に謝意を表する.

\section{参考文献}

1）幸福度に関する研究会：幸福度に関する研究会報告 一幸福度指標試案一。 46pp, 2011.

2) 中口毅博 : 日本のローカルアジェンダ 21 の評価と課 題. 環境科学会誌, 14(1), 108-109, 2001.

3) 沼田壮人：広義のストック概念に着目した持続可能 な都市・地域のマネジメント。季刊 政策・経営研究 2008，4，154-165, 2008.

4) 沼田壮人：持続可能な都市づくりに向けた自治体の 事業と計画. 財政と公共政策，52，107-121， 2012.

5) Steurer, R. and Hametner, M. : Objectives and Indicators in Sustainable Development Strategies: Similarities and Variances across Europe. Sustainable Development, 21(4), 224-241, 2013. (online 2010)

6) Murayama, M., Matsuhashi K., Lim H. : A perspective of the local visions for sustainable development through the analysis on the comprehensive plan of the Eco-Model City in Japan. Proceedings of Intemational Symposium on City Planning 2013, 2013.

7) Cutter, A., Osbom, D., Romano, J., Ullah, D.: Sustainable Development Goals and Integration. Stakeholder Forum, 24p, 2015.

8) 谷口守, 肥後洋平, 落合淳太 : 都市計画マスタープラン に見る低炭素化のためのコンパクトシティ政策の現状. 土木学会論文集G (環境)，68(6)，II_395-II_402，2012.

9) 松橋啓介, 村山麻衣, 増井利彦, 原澤英夫 : 持続可能社 会への転換に向けた叙述シナリオ構築に関する試み一生 産活動の観点から一． 環境科学会誌，26(3)，226-235，2013.

10) ジャパン・フォー・サステナビリティ: 持続可能な日本 の社会を考える. 倉敷印刷, $142 \mathrm{pp}, 2007$.

11) Meadows, D.: Indicators and Information Systems for Sustainable Development. The Sustainability Institute, Hartland, VT. 78 pp, 1998.

12) Dasgupta, P.: Human Well-Being and the Natural Environment. Oxford University Press, 328pp, 2001.

13) Ekins, P., Dresner, S. and Dahlstrom, K. : The Four-Capital Method of Sustainable Development Evaluation. European Environment, 18, 63-80, 2008. (online 2007)

14) OECD: Better Life Index. http://www.oecdbetterlifeindex.org/, 2015.

15) IHDP: Inclusive Wealth Index. http://inclusivewealthindex.org/, 2014.

16) Rio+20: The future we want. http://www.un.org/en/sustainablefuture/ 49 pp, 2012.

(2015.7.27受付)

\section{An Experimental Approach to Evaluation of Basic Goals in Municipalities on Sutainable Development Targets}

\section{Keisuke MATSUHASHI and Aki NAGANO}

The Sustainable Development Goals are discussed around UN. For promoting sustainable development, it is effective to integrate the sustainable development targets into the comprehensive plan and strategically implement them. This study investigates the basic strategies in the comprehensive plan of 23cities which are designated as the Eco Model Cities in Japan and evaluate the percentages of the sustainable development targets contained in the basic strategies is evaluated. The criteria which was previously conducted in two workshops is applied in this process. The result shows that the ratio of environment is quite low especially in headlines. It is required to balance among environment, economy, society and human welbeings in local cities vision. 